\title{
DEVLET TARAFINDAN DÜZENLENEN ÜREMEYE YARDIMCI TEKNOLOJİLERİN KULLANIMI VE DEMOGRAFİK SÜREÇ ${ }^{1}$
}

\section{Şafak KILIÇTEPE ${ }^{2}$}

\section{$\ddot{O} z$}

Türkiye, gittikçe azalan toplam doğum hızının (TDH) gelecekteki iş gücü açısından tehlike yaratacağına işaret ederek, on yılı aşkın bir süredir pronatalist nüfus politikaları uygulamaktadır. Türkiye İstatistik Kurumu verilerine göre Türkiye'nin TDH'si, genel olarak, yenilenme düzeyi olan 2.10'un altına düşmüş olsa da TDH bölgesel farklılıklar göstererek, bu bölgelerin demografik süreçlerinin farklılığına dikkati çekmektedir. Pronatalist nüfus politikaları doğrultusunda, devlet evli çiftlerin ilk üç tüp bebek tedavisini desteklemektedir. Ancak, yaygın olarak kullanılan tüp bebek ya da teknik ifadesiyle üremeye yardımcı teknolojilerin (ÜYT) erişimi ve kullanımı da devlet düzenlenmesi ve kontrolü altındadır. Etnisite ve toplumsal cinsiyet kategorilerinin bölgesel farklılık gösteren demografik süreçteki (evlilik, üreme ve boşanma ile ilgili kararları) yerini analitik olarak irdeleyen bu çalışma, Kürt kadınlarının üremeyle ilgili deneyimlerini merkezine almaktadır. Böylece, devlet tarafından düzenlenen ÜYT’nin demografik süreci nasıl etkilediğine bakıp, demografi ile ilgili veri ve istatistiklerin yereldeki sosyopolitik tarih ve yapı, iktidar ilişkileri, pratik ve inanışlarıyla beraber nasıl (yeniden) şekillenebileceğini göstermektedir.

Anahtar Kelimeler: Üremeye Yardımcı Teknolojiler, Yönetimsellik, Demografik Süreç

\footnotetext{
${ }^{1} \mathrm{Bu}$ araştırmayı destekleyen ve araştırmaya fon sağlayan Social Science Research Council Mellon International Dissertation Research Fellowship, National Science Foundation Doctoral Dissertation Research Fellowship, Indiana Üniversitesi'nin Center for Research on Race and Ethnicity in Society Graduate Student Research Award, ve Mellon's Innovating International Research, Teaching and Collaboration Graduate Dissertation Fellowship araştırma kurum ve kuruluşlara teşekkür ederim. 2 Öğr. Gör. Dr., Kırşehir Ahi Evran Üniversitesi Fen Edebiyat Fakültesi, Antropoloji Bölümü 
Devlet Tarafindan Düzenlenen Üremeye

\title{
THE USE OF STATE REGULATED ASSISTED REPRODUCTIVE TECHNOLOGIES AND DEMOGRAPHIC PROCESS
}

\begin{abstract}
Over the ten years, Turkish government has announced its pronatalist population politics due to the decline in the total fertility rate (TFR), considered a threat for its future labor force. According to Turkish Statistical Institute, TFR has declined below the replacement level of 2.10. The statistics shows existing regional differences in TFR, indicating variations in their demographic processes. As a pronatalist country, the Turkish state provides funding for married couples in their in vitro fertilization, known also as assisted reproductive technologies (ARTs), treatment up to three times. Yet, access to ARTs, used widely in Turkey, is strictly state-regulated and controlled. Examining ethnicity and gender as analytical categories in the formation of demographic process (decisions about marriage, divorce and reproduction), which shows regional differences, this study focuses on Kurdish women's reproductive experiences. Thus, this article reveals how the state-regulated-ARTs affect the demographic process and how the demographic data and statistics are (re)shaped by the sociopolitical structure, power relations, practices and beliefs at the local.
\end{abstract}

Keywords: Assisted Reproductive Technologies, Governmentality, Demographic Process 


\section{GİRIŞ}

Bu makalenin amacı, hem iktidar dinamiklerinin hem de kesişen kimlik deneyimlerinin (etnisite, sınıf, toplumsal cinsiyet gibi) kamu çalışanı olarak doktorlar ve Üremeye Yardımcı Teknolojiler (ÜYT) yoluyla infertilite veya, görüştüğüm kişilerin tanımıyla, 'kısırlık,' 'çocuk tedavisi,' arayan hastaların iletişimi sonucu nasıl yeniden üretildiğini, kopyalandığını, bükülüp, yerinden edildiğini göstermektir. ÜYT'ye dair düzenlemeleri yönetimselliğin (governmentality) bir formu olarak ele alan bu makale, toplumsal ve siyasi yapının, kurumsal düzenlemelerin, üremeyle ilgili karşılaşmaların ve öznelerin failliklerinin nasıl kesiştiğine ve bu kesişmelerin üremeyle ilgili olasılıkları, kararları nasıl şekillendirdiğine bakarak, bunların Türkiye'de yaşayan Kürtlerin demografik sürecine ne tür katkılar sağladığını göstermektedir. Üremeye dair eğilimler, iktidar farklılaşmaları, çiftlerin ve grupların üremeyle ilgili farklı istekleri ve davranışlarından dolayı çeşitlilik göstermektedir (Schneider \& Schneider, 1995). Bu makale, böylesi farklılıkları anlayabilmek için, üreme teknolojilerini lens olarak kullanıp hem ulusal hem de yerel dinamiklere yakından bakmamız gerektiğini önermektedir.

Bağlam vermek gerekirse, 2002'de yönetime geçen Adalet ve Kalkınma Partisi (AKP) hükümeti ülkenin toplam doğum hızının $(\mathrm{TDH})^{3}$ hızla düşmesi konusunda alarma geçerek, ülkenin (Sunni İslamcı) pronatalist üreme politikalarına ihtiyacı olduğunu savunmaktadır. Ülkenin global ekonomideki yerini sağlamlaştırmak için genç iş gücüne ihtiyacı olduğunu belirten hükümet, evli çiftleri 'en az 3 çocuk' yapma konusunda teşvik etmektedir (Korkman, 2015). Nüfusu artırmaya yönelik girişimlerden biri doğal yollarla çocuk sahibi olamayan çiftlerin, masraflı olan tüp bebek tedavisini de içine alan infertilite

${ }^{3} \mathrm{TDH}$ bir kadının hayatı boyunca dünyaya getirdiği ortalama çocuk sayısıdır. 
tedavilerini karşılamaktır ${ }^{4}$. Devlet, genel sağlık sigortası olanların ilk üç tüp bebek tedavisini cömert bir şekilde desteklerken, bu desteği evli olan çiftler ve $23-40^{5}$ yaş arasında olan kadınlarla sınırlamıştır ${ }^{6}$.

Devletin pronatalist çağrılarına ve doğumu teşvik eden politikalarına karşın, TDH son yarım yüzyılda devam eden bir şekilde düşmektedir. Örneğin, 1960 nüfus sayımına göre, TDH 6.18 iken (Shorter, 1968), 2019 nüfus sayımına göre, TDH 1.99'a düşmüştür (Türkiye İstatistik Kurumu (TÜİK), 2019 Basın Duyurusu). Bu oran nüfusun kendini yenileme seviyesi olarak belirlenen 2.10'un altındadır? TÜIK 2018 verilerine göre, en yüksek TDH'ye sahip illerden ilk onu Kürtlerin yoğunlukta yaşadığ1 yerlerdir. Bu illerdeki ortalama doğum hızı, genel oranın tersine, 3.4 ile nüfusun kendini yenileme seviyesinin üzerindedir. Ancak, bu orana rağmen, Türkiye genelinde TDH oranının en hızlı düşüşü de yine Kürtlerin yoğun olarak yaşadığı Türkiye'nin doğu ve güneydoğusunda gerçekleşmektedir. Kürtlerin yaşadığı bölgelerde TDH'nin Kürtlerin daha az yaşadığı bölgelerden farklı, fakat hızlı olan düşüşü hem bu bölgelerin farklı demografik süreçlerden geçtiğine hem de kadınların içinde yaşamış olduğu toplumsal pronatalizme işaret etmektedir (Yavuz, 2005; Zeyneloğlu vd, 2016) ${ }^{8}$. Toplumsal pronatalizm kadını her şeyden önce erkek soyunun taşıyıcısı ve çoğaltıcısı olarak konumlandırıp, onun

\footnotetext{
${ }^{4}$ Türkiye dünyanın en hızlı büyüyen ÜYT piyasalarındandır. Sağlık Bakanlığı tarafından sağlanan verilere göre (2017), 2015 yılında Türkiye'de ruhsatl1 152 tüp bebek merkezi bulunmaktadır. Üreme Sağlığı ve İnfertilite Derneği'nin raporuna göre, 2010 yılında bu sayı 110 civarındaydı (Urman \& Yakin, 2010). Giderek büyüyen bu piyasa hem Türkiye vatandaşlarına hem de Türkiye vatandaşı olmayıp, ülke dışından gelen bireylere hizmet vermektedir.

${ }^{5}$ Araştırmayı gerçekleştirdiğim sırada tüp bebek ödeneği sağlanması için yaş aralığı 23 ve 39 idi. 2018 'de 23 ile 40 yaş arasında olma koşulu getirildi.

6 Türkiye'de ÜYT sıkı bir şekilde düzenleyip kontrol edilmektedir. Türkiye dünyada bir ilke imza atarak, İslam dinine aykırı olduğu ve 'Türk soyunu koruma' amacı gerekçeleriyle, 2010 yılında kendi vatandaşlarının hem yurt içinde hem de yurt dışında gamet (yumurta ve/ya sperm) bağışı aramasını kanunla yasaklayıp, üçüncü parti üreme yolu arayanlara veya teşvik eden doktor ve hastanelere cezai işlem uygulamaktadır (Gürtin, 2011; Urman \& Yakin, 2010). 2018'de bu yasak daha da genişletilmiştir. Yeni düzenlemeye göre, üçüncü parti üreme sürecinde yer alan bütün taraflar (doktorlar, bağış yapanlar, ara bulucular ve donasyona teşvik eden kişiler gibi) beş yıla kadar hapis cezasına tâbi tutulmaktadır. Bkz, "Sağlıkla İlgili Bazı Kanun ve Kanun Hükmünde Kararnamelerde Değişiklik Yapılmasına Dair Kanun," Resmi Gazete, 5 Aralık 2018. 20 Temmuz 2020 tarihinde erişildi. Ayrıca bkz, "New legislation expands ban on sperm and egg donations in Turkey," Hürriyet Daily News, 9 Kasım, 2018. 5 Nisan, 2018 tarihinde erişildi. http://www.hurriyetdailynews.com/new-legislation-expands-ban-on-sperm-and-eggdonations-in-turkey-138719. Bkz, "Sperm bankasından bebek yapana 3 yıl hapis," Hürriyet. 15 Mart, 2010. 26 Ekim, 2018 tarihinde erişildi. http://www.hurriyet.com.tr/gundem/sperm-bankasindan-bebek-yapana-3-yil-hapis-14109315

7 Bkz, "Türkiye'nin doğum istatistikleri açıklandı," CNN TÜRK. 17 Mayıs, 2019. 10 Nisan, 2020 tarihinde erişildi. https://www.cnnturk.com/turkiye/turkiyenin-dogum-istatistikleri-aciklandi

${ }^{8}$ Toplumsal pronatalizm ile kadınların çocuk sahibi olma, üreme, annelik gibi olgulardan dolayı maruz kaldıkları toplumsal baskıya işaret ediyorum. Bu terimi kullanarak Kürt kadınları hakkında halihazırda var olan ve onları dışlayan 'aşırı doğurgan' algısını beslemek yerine, aslında toplumsal pronatalizmin çokluğuna hem mikro hem de makro seviyede sosyo-ekonomik ve politik şartlarla şekillendiğini vurguluyorum.
} 
Devlet Tarafindan Düzenlenen Üremeye

ailedeki yerini üreme kapasitesine bağlı tutar. Kadınlığın doğurganlık üzerinden tanımlandığı böylesi bir patriarkal çevrede, (hem kadından hem de erkekten kaynaklanan) infertilite kadına daha fazla sorumluluk yükler. Çeşitli nedenlerden dolayı (daha fazla) çocuk sahibi olamadıkları için, kadınlar fiziksel şiddetten, psikolojik ve sosyo-ekonomik şiddete kadar muhtelif şiddet şekilleriyle karşı karşıya kalabilmektedirler. Nüfusa dair veya demografik veriler ise böylesi deneyimler sonucu ortaya çıkmaktadır (Greenhalgh, 1995).

Nüfus ile ilgili veriler üremeye dair pratikleri etkileyen ve şekillendiren çeşitli ulusal, yerel ve medikal dinamiklerin aile içi kararları şekillendirmesiyle ortaya çıkar. William Skinner (1997)'e göre, materyal olan demografik verilerle sonuçlanan demografik süreç evlilik, boşanma ve (doğum oranlarını da içine alan) üreme ile ilgili kararları etkileyen dinamikler sonucudur. Skinner, ailevi süreçlerle (evlilik, üreme ve göç gibi kararların alındığı yer olarak) demografik sürecin iç içe geçtiğini ve bu iç içe geçmişliklerinden dolayı ikisine aslında tek bir sistem olarak muamele edebileceğimizi söyler (Skinner, 1997). Bireylerin devlet tarafından düzenlenen üreme teknolojileri ile ilgili deneyimlerine eğilmek hem biyopolitikaların hem de yönetimselliğin yerelde nasıl işlediğini göstererek, böylesi teknolojilerin evlilik, üreme, boşanma gibi olgulara dair inanış ve pratiklerle karşılaştığında demografik süreci nasıl etkileyeceğini ortaya koymaktadır (Greenhalgh, 1995). Bireylerin üreme teknolojileri ile ilgili deneyimleri karmaşık olan merkezi/yerel iktidar ilişkileri ve yapısal eşitsizliklerle kesiştiği için demografik sürecin sosyopolitik tarihsel yapılanmasına dair bilgiler de sunmaktadır. Bu karmaşık ilişkililiği ve nüfusun yapılanmasına dair iç içe geçmiş çoklu dinamikleri kapsadığından, Türkiye'de yaşayan Kürtler bu çalışma için önemli bir yer teşkil etmektedir. Türkiye'de yaşayan Kürtler homojen bir grup değillerdir. Sınıf, aile ve toplumsal cinsiyet anlayışı, pratik ve inanışları farklılık göstermektedir. Bu bağlamda, devletin ÜYT düzenlemeleri, bireylerin hem farklı sosyoekonomik 
konumlarından hem de evlilik ve yaş durumlarından dolayı tabakalaşmış üreme deneyimlerine yol açmaktadır ${ }^{9}$.

\section{SOSYOPOLITIIK BAĞLAM VE ÇALIŞMANIN LITTERATÜRDEKİ YERI}

2016'da 17 ay sürecek olan etnografik araştırmamı yapmaya başladığım süreç, Türkiye ve PKK (Kürtçe: Partiya Karkerên Kurdistanê, [Türkçe: Kürdistan İşçi Partisi]) arasında Çözüm veya Barış Süreci (20132015) olarak adlandırılan sürecin bitmesinin akabindeydi. AKP ${ }^{10}$ hükümeti tarafından başlatılan Çözüm Süreci ile özellikle Türkiye'nin doğu ve güneydoğusunda otuz yılı aşkındır devam etmekte olan, ciddi can ve mal kaybı ile yerinden edilmelere yol açan silahlı çatışmaları sonlandırıp, güvenliği ve demokratik pratikleri artırmak amaçlanmaktayd ${ }^{11}$. Çözüm Süreci, Türkiye'de 2013’te, 2015 Temmuz'a kadar iki yıl sürecek olan ateşkesle sonuçlandı. Çatışmalardan en fazla etkilenen vatandaşlardan Diyarbakır'da tanıştı̆̆ım Kürt görüşmecilerim ateşkes sürecinin hayatlarındaki 'en huzurlu zamanlar' olduğunu belirtmişlerdi. Fakat, ateşkes 2015 ’te sonlandırıldı ve silahlı çatışmalar şehir merkezlerine taşınarak 'normal' hayatı derinden sarstı. Ateşkesin sona ermesi birçok insanın can kaybına ve özellikle Doğu ve Güneydoğu'nun Diyarbakır'ı da içine alan bazı illerinde büyük yıkımlara yol açtı12. Ayrıca, aktif çatışmalar zorunlu göç, yerinden edilme ve sosyoekonomik kayıplara da neden oldu. Elizabeth Dunn (2017), böylesi bir siyasi ekonomiyi ‘insanın hayatını değiştiren’ “büyük harf-O ile ‘Olay”” olarak

\footnotetext{
${ }^{9}$ Tabakalaşmış üreme (stratified reproduction) kavramı, 1986 yılında, ilk kez Shellee Colen tarafından, Hindistanlı bakıcı kadın işçilerin New York’taki konumlarını açıklamak için kullanılmıştır. Colen, ırk, etnisite, cinsiyet, sınıf ve göçmenlik temelli eşitsizliklerin kadınların üreme ile ilgili deneyimlerini farklı biçimlerde şekillendirdiğini söylemektedir. Bu kavram şu anda feminist akademisyenler tarafından, üremeye dair pratikler ve deneyimlerle ilgili eşitsizlikleri açıklamak için yaygın bir şekilde kullanmaktadır. Bakınız Colen, S. (1995). 'Like a Mother to Them': Stratified Reproduction and West Indian Childcare Workers and Employers in New York. Conceiving the New World Order: The Global Politics of Reproduction içinde, yay. haz. Faye D. Ginsburg ve Rayna Rapp, 78-102. Berkeley, CA: University of California Press.

10 2002'den beri iktidarda olan Adalet ve Kalkınma Partisi (AKP), siyasi kimliğini "muhafazakar-demokrat" olarak tanımlamaktadır.

11 Süreç 2014'te yayınlanan bildirge ile kanunlaştırılmıştır (Kanun No. 6551): “Terörün Sona Erdirilmesi ve Toplumsal Bütünleşmenin Güçlendirilmesine dair Kanun,” Resmî Gazete, 16 Temmuz 2014. 15 Temmuz 2020 tarihinde erişildi. https://www.resmigazete.gov.tr/eskiler/2014/07/20140716-1.html

${ }^{12}$ Güvenlik gerekçesiyle, bazı yerlerde aylar süren, süresiz sokağa çıkma yasakları uygulandı. Çatışmalar, Diyarbakır, Şırnak, Nüsaybin, Yüksekova gibi yerlerde büyük alanlarda tahribatlara yol açıp yıkımlara sebep oldu. Birleşmiş Milletler İnsan Hakları Yüksek Komiserliği'nin raporuna göre (2017), 2015 Temmuz ve 2016 Aralık aylarında Türkiye'nin güneydoğusunda gerçekleşen operasyonlar 30'dan fazla ilçe ve mahalleyi etkilemiştir. Çoğunluğu Kürt olan 355,000 ile 500,000 arasında kişi ise yerinden edilip sosyo-ekonomik mahrumiyete maruz bırakılmıştır.
} 
tanımlar. Belirtmek gerekir ki, Türkiye ile PKK arasındaki çatışma dinamikleri genel toplumun normal hayatını büyük ölçüde etkilemiş ve şekillendirmiş olsa da, Türkiye'de yaşayan ve $O$-lay'lara farklı şekillerde bire bir maruz kalan kişileri, yani çoğunlukla Kürtleri, eşit olmayan bir şekilde daha fazla vurmuş ve var olan yapısal eşitsizliklerini daha da derinleştirmiştir ${ }^{13}$.

Antropolojik nüfus bağlamında, ulusal nüfus verilerinin nasıl şekillendiğini anlamak için iktidar dinamiklerinin, yapısal eşitsizlik, toplumsal inanış ve pratiklerinin yerelde bireylerin üreme ve üreme ile ilgili deneyim, pratik ve kararlarını nasıl şekillendiğine yakından bakmamız gerekmektedir. Yani, Kürtlerin, Türkiye'de yaşayan diğer etnik ve dini gruplardan farklı bir demografik geçiş süreci göstermeleri sadece etnik kimliklerinin uzantısı olarak değerlendirilmemeli, hem çoklu ulusal ve yerel iktidar dinamiklerine hem de nüfus düzenlemelerinin yansımaları olarak incelenmelidir. Bu makale için, ÜYT ise böylesi dinamiklere yakından bakabilmek açısından bir lens sağlamaktadır.

Devlet tarafından (bazı bireyler için) desteklenen ve düzenlenip kontrol edilen üreme teknolojileri, hem üreme yönetiminin (reproductive governance) hem de devletin arzu ettiği vatandaşların kimler olarak hayal edildiğini ve işlendiğini gösteren nüfus politikalarının bir parçası, yansımasıdır (Morgan \& Roberts, 2012). Bazı araştırmacılar, ebeveyn ve nüfus inşasını (making) şekillendiren üreme teknolojilerinin, demografik süreçteki çarpıcı katkısına özellikle değinmişlerdir (Greenhalgh \& Li, 1995; Thompson, 2005). Elizabeth F.S. Roberts (2012), Ekvator'da üreme teknolojileri üzerine yaptığ çalışmasında, üreme teknolojileri yoluyla ortaya çıkan bu 'inşa sürecinin' teknolojinin yer aldığı bölgeye özgün pratiklerle yakından ilişkili olduğunu ortaya koymuştur. Dahası, üreme yönetimi fikriyle çalışarak, Ekvator'da ideal üreme teknolojileri olarak nitelendirilen şeyin aslında bölgeye özgün olan

\footnotetext{
${ }^{13}$ Hacettepe Üniversitesi Nüfus Etütleri Enstitüsü'nün yapmış olduğu Türkiye'de Göç ve Yerinden Olmuş Nüfus Araştırması (2006) ve Türkiye Ekonomik ve Sosyal Etüdler Vakfi'nın (2005) raporlarına göre bir milyondan fazla kişi zorunlu göçe tâbi tutulmuştur. Özellikle Güneydoğu'da göçler 'güvenlik' nedeniyle yaşanmıştır ve yaşayanları daha fazla sosyo-ekonomik güvensizlik ve belirsizliğe sürüklemiştir (ayrıca bkz, Mutlu, 2001; İçduygu, vd., 1999).
} 
ırk tarihi, özellikle ırksal dövülgenlik (racial malleability) ve Andes'deki akrabalık anlayışlarıyla şekillendiğini göstermiştir ${ }^{14}$.

Özellikle Türkiye'de ÜYT’nin ulusal ve uluslararası kullanımının tırmanışıyla, Türkiye üzerine odaklanan feminist bilim ve teknoloji çalışmaları da son yıllarda öne çıkmıştır (Goknar, 2015; Gürtin, 2011; Gürtin-Broadbent, 2013; Mutlu, 2017; Polat, 2017). Ancak, politik ve değişen çevrelerde yaşayan etnik gruplara ait bireylerin ÜYT'yi ve ÜYT düzenlemelerini bireysel, toplumsal ve ulusal düzeylerde nasıl deneyimledikleri konusu üzerinde yeterince durulmamıştır. Aynı zamanda, Türkiye'de nüfusa dair çalışmalar oldukça zengin olsa da, bu literatür üremeye müdahalelerin ve teknolojik gelişmelerin bir toplumun demografik sürecini (evlilik ve üreme ile ilgili kararları etkileyen cinsiyet, aile, etnisite ve ulus gibi kavramlar) yerelde nasıl şekillendirdiği sorusuna cevap vermekte yetersiz kalmıştır. Jill R. Williams (2010), "Feminist Demografi Yapmak" adlı makalesinde, demografik çalışmalarda cinsiyet gibi sosyal olarak inşa edilmiş bir kategorinin basitçe biyolojik olarak görüldüğünden bahseder. Türkiye demografi çalışmalarında hem cinsiyeti hem de etnisiteyi basit kategoriler olarak ele almayan çalışmalar $\operatorname{azdı1}^{15}$. Bu kavramların sosyopolitik ve ekonomik inşasının bireylerin günlük hayatlarını nasıl şekillendirip üreme ve üremeye dair kararlarda nasıl rol oynadıkları ile demografik süreci nasıl şekillendirdikleri üzerine derinlemesine analizler yapılmamaktadır (Aysan, 2014; Hacettepe Üniversitesi Nüfus Etütleri Enstitüsü, 2006; İçduygu ve ark., 1999; Koç ve ark., 2000; Mutlu, 1996; Smits \& Gündüz-Hoşgör, 2003; Yavuz, 2006; Yüceşahin, 2009). Ancak, bu makalede de görüleceği üzere, toplumsal cinsiyete dair performans/pratik ve algılarla kişilerin üreme ve üreme teknolojilerini nasıl deneyimleyip, bunların sınıf, cinsiyet ve etnisiteye bağlı kimliklerini nasıl etkiledikleri yakından ilintilidir. Bu anlamda, üreme teknolojilerinin kullanımı, erişimi ve üremeye dair düzenlemelerin ortaya

\footnotetext{
${ }^{14}$ Elizabeth F.S. Roberts (2012) ırksal dövülgenlik kavramı ile, Ekvator'daki ırk kavramının materyal bir anlamı olduğuna ve materyal olanın ise uydurulabileceği ve değiştirebileceğine işaret eder.

${ }^{15}$ Ferhunde Özbay toplumsal cinsiyeti basit bir kategiri olarak görmez. Aksine, Özbay, demografik verilerin yorumlanması ve nasıl şekillendiğini anlamak için, tarihsel bağlam ile toplumsal, ekonomik, politik ilişkilerin gündelik hayayatla nasıl bir ilinti halinde olduğuna bakmamız gerektiğini savunan bir sosyologtur. Bkz, Özbay, F. (2015). Dünden bugüne aile, kent, nüfus. İstanbul: İletişim Yayınları. Bkz. Özbay, F., \& Yücel, B. (2001). Türkiye'de Nüfus Hareketleri, Devlet Politikaları ve Demografik Yap1. Nüfus ve Kalkinma, 1-69.
} 
çıkardığı ilişki ve müzakereler demografik sürece yön vermektedir. Eleştirel çalışmalar, çeşitli güç dinamiklerinin ve global ilişkilerin demografiyi nasıl şekillendirildiği konusundaki anlayışımızı ileriye taşımış olsa da, bu çalışmaların çoğu Batı toplumları üzerinedir (Ginsburg \& Rapp, 1995; Greenhalgh, 1995). Batılı olmayan toplumların da demografilerini ve demografik süreçlerini anlamlandırabileceğimiz, kavramsallaştırıp kendi tarihsel dokuları içerisinde anlayabileceğimiz araçlar geliştirebilmemiz önemlidir (Rivkin-Fish, 2003). Bulgularına etnografik araştırma yöntemiyle ulaşmış olan bu çalışma, üreme teknolojileri kullanımının ve düzenlemelerinin etnik bir grubun demografik sürecini nasıl şekillendirdiğine odaklanarak, Batılı olmayan toplumlara dair araçlar sunmak açısından örnek teşkil eder.

\section{YÖNTEM}

Bu makale, Kürt kadınlarının üremeyle ilgili deneyimlerine odaklanan, uzun süren çok-sahalı (multisited) etnografik doktora tez araştırmamdan faydalanmaktadır (Kılıçtepe, 2019). Doktora tez araştırması, genel olarak, siyasi çalkantıların yoğun olduğu bölgelerde yaşayan kadınların üreme ve infertilite ile ilgili deneyimlerinin, Türkiye'nin değişen azınlık politikaları ve devletin ÜYT düzenlemeleriyle kesişip kesişmediğine ve varsa nasıl ve ne derece kesişme olduğuna bakmaktadır. Tez araştırması, 2012 ile 2014 yılları arasında dört buçuk ay süren ön saha araştırmalarına ek olarak, 2016 ve 2017 yıllarında kesintisiz on yedi ay süren sistematik etnografik araştırmalar bütünüdür. Biyolojik üremenin toplumsal anlam ve bireysel deneyimlerini onun zengin olan sosyal, kültürel, politik alanında incelemek ve aidiyet politikalarını tespit etmek hem stratejik hem de birbirini destekleyen metodolojik araçları gerektirmektedir. Bu sebeple, bu çalışmada, George Marcus (1995) tarafından tanımlanmış olup geleneksel tek-sahalı metodolojik yaklaşımdan uzaklaşmış, çok-sahalı etnografi modeli kullanılmıştır. Veriler, birbirini tamamlayan üç yaklaşım yoluyla toplanmıştır: (1) katılımcı gözlem, (2) hususi konuşmalar ve yapılandırılmış görüşmeler ve (3) soruları yarı-yapılandırılmış derinlemesine görüşmeler. Çok-sahalı araştırma, sosyo-kültürel farklılıklara ev sahipliği yapan başkent Ankara'da 5 ay ve Kürtlerin yoğunluklu yaşadığı büyükşehir Diyarbakır'da 12 ay olmak üzere toplam 17 ay sürmüştür. Araştırma, (resmi izin alınarak) özel ve devlet hastanelerinin infertilite ve kadın doğum 
Devlet Tarafindan Düzenlenen Üremeye

bölümleri, farklı sosyo-ekonomik gruplara ait olan mahalle, ailelerin evleri ve kamusal alanlarda olmak üzere katılımcı gözlem yapılarak; görüşmeler ise infertilite tedavisi gören bireyler (kadın ve erkek), doktorlar, sağlık/hastane çalışanları, evli veya bekar kadın ve erkekler, kadın merkezleri ve dernekleri gibi sivil toplum örgütleri ve bürokratlarla yapılmıştır.

Michel Foucault ve Paul Rabinow, iktidar teknolojilerinin toplumları idare ve kontrol etmenin yollarındandır der (Foucault, 1978, 2003; Rabinow, 2005). Hastane ortamları iktidar ilişkileri ile tarihsel olarak konumlanmış bilgilerin, toplumsal cinsiyete dair pratik ve performanslarını gözlemleyeceğimiz yerlerdendir (van der Geest \& Finkler, 2004). Klinikler ve hastaneler toplumsal cinsiyet, aile dinamikleri, üremeye dair arzular, kararlar; fertil/infertil olma durumuna dair algılar ve devletin üremeye dair medikal düzenlemelerinin müzakere edildiği alanlardandır. Bu makale, 2016 ve 2017 y1llarında, Diyarbakır devlet hastanesinde, kesintisiz 3 ay gerçekleştirdiğim katılımcı gözlem ve hususi görüşmelerden esinlenerek ortaya çıkmıştır. Bulgular, özel tüp bebek merkezinde yapmış olduğum hem katılımcı gözlem hem de sohbetler ve görüşmelerim (kesintisiz toplam 6 ay), ve hastanelerin dışında gerçekleştirmiş olduğum etnografik araştırmalarla desteklenmiştir. Böylesi geniş bir yelpazede kendimi araştırmacı olarak konumlandırmak, bireylerin üreme ve üremelerine dair deneyimlerinin nasıl ve ne yollarla şekillendiğini çok boyutlu olarak görmeme olanak sağlamıştır.

Bu çalışma, Türkiye'deki araştırmalarımı yürüttüğüm devlet hastanelerinden aldığım etik kurul onayları öncesinde, Indiana Üniversitesi'nin Kurumsal Etik Kurulu (Institutional Review Board [IRB]) tarafından 19 Mayıs, 2015 tarihinde onaylanmıştır. IRB tarafından izin verilen araştırma (study\# 1502765023) katılımcıların gizliliklerini anonimlik ve sözlü rıza ile garantilemiştir. Bu araştırmada geçen kişilerin isimleri gerçek olmayıp, anonim isimler kullanılmıştır. Araştırmaya katılan kişileri ilk olarak araştırmaya dair sözlü olarak bilgilendirip, katılıp katılmak istemedikleri, katılmak istiyorlarsa seslerini kayıt cihazıyla kaydetmem konusunda rızaları olup olmadığı sorulmuştur. Diyarbakır hastanelerindeki katılımcıların birçoğu görüşmeleri kabul etseler de seslerini kaydetmem konusunda rızaları olmadığından, görüşmeler sırasında yalnızca notlar alınmıştır. Diyarbakır'daki özel hastanede 
Devlet Tarafindan Düzenlenen Üremeye

infertilite tedavisi gören hastalarla gerçekleştirdiğim 50 görüşmenin sadece 10'unun ses kaydı alınmasına izin verilmiştir. Katılımcı gözlem sırasında ise, herhangi bir ses kayıt cihazı kullanılmamış ve yalnızca notlar alınmıştır. Devlet hastanesinde, mesai saatleri içerisinde kadın doğum ve infertilite kliniklerinde çalışanlarla konuşup, hastalar, hastaların birbirleriyle ve doktorlarla olan iletişimlerini gözlemlenmiştir. Araştırmamda istatistiksel verilere başvurmuş olsam da önemle belirtmek gerekir ki, bu makale istatistiksel veri ve analizi üretmemektedir.

\section{DOKTORLAR TARAFINDAN ALINAN KARARLAR VE DEMOGRAFÍK SÜREÇ}

Diyarbakır'da Kadın Doğum Hastanesi'ndeki kadın doğum doktorlarının diğer kliniklerden ayrı bir infertilite kliniği açması aslında ihtiyaç sonucuydu. Devlet hastanesinde alan araştırmama başladığım sırada, yeni açılacak olan infertilite kliniğinin hazırlıkları henüz yapılmaktaydı. 'Çocuk tedavisi' için gelenlerin çok oluşu ve böylesi hastalara daha iyi hizmet verebilmek için, infertilite tedavisi eğitimi almış beş doktorun dönüşümlü çalıştığı infertilite kliniği Ocak 2017'de Diyarbakır Kadın Hastalıkları Doğum ve Çocuk Hastalıkları Hastanesi’nde açıldı. Fakat, diğer kadın doğum kliniklerinde olduğu gibi, infertilite kliniğine gelen kadın profili de oldukça geniş bir yelpazeye sahipti. Yani, klinikten sıra alıp, akşama kadar sıra bekleye(bile)n kadınlar arasında hiç çocuk sahibi olmamış kadınlardan, 7 çocuğu olup daha fazla çocuk sahibi olmak isteyen kadınlara kadar geniş kapsamlı bir hasta profili mevcuttu. Hastalar sıra sistemi ile içeri alındığı ve kliniğin yoğunluğundan dolayı, bazı günler hiç çocuğu olmayan kadınlara sıra gelmiyor ve bu kadınlar evlerine elleri boş dönmek zorunda kalıyorlardı. Böylesi bir durum ise infertilite kliniğinin açılış amacına hizmet etmemekteydi. Son tahlilde, doktorlar bu kliniği çocuk sahibi olamayan hastalara daha doğru hizmet verebilmek için açmışlardı. Amaçlarını tekrar gözden geçirerek, infertilite kliniğinde çalışan doktorlar kolektif fakat resmi olmayan bir düzenlemeye gitmek zorunda kaldılar: kliniğe kabul edilecek kadınların çocuk sayısı 3 çocuktan az olmalıydı. Polikliniğin açılışının üçüncü haftasından sonra artık üç ve fazlası çocuk sahibi olan kadınlara bu poliklinikte infertilite muayenesi ve tedavisi uygulanmayacaktı. 
Hastanenin kısıtlı şartlarından ve devlet çalışanları olma konumlarından dolayı, doktorlar, bu bağlamda, düzenlemeleri düzenleyen bürokratlar olarak konumlandırılmışlardı. Yani, bu 'küçük' poliklinikte geçen mikro düzenlemelerle kimlerin (hangi Kürt kadınının, olarak okuyun) infertilite tedavisi alıp almayacağı gibi büyük nüfus düzenlemelerine sebep olabilecek bir karar verilmişti. Üç ve fazlası çocuk sahibi olmuş, fakat artık çocuk sahibi olamayıp üremeye dair konumlandırılmış bilgilerinden dolayı kendilerini infertil olarak pozisyonlandıran kadınların varlığını reddeden bu düzenleme, kadınların hâli hazırda sınırlı olan tedaviye erişimlerini daha da kısıtlamaktaydı. İki çocuktan fazla çocuğu olan kadınlara, doktorlar özel hastanelerin yolunu gösteriyorlardı. Fakat, devlet hastanesine gelen kadınların birçoğu, özel hastanelere bütçe ayırabilecek durumda olmayan alt sınıftan kadınlardı. 'Üç çocuktan az' kararı, genel üreme düzenlemeleri gibi, yine kadınların etnik, sınıfsal, toplumsal cinsiyet gibi kimliklerini ve bu kesişimsellikdeki konumlandılmışlıklarını görmezden gelip üremeye dair yeni eşitsizlikler ortaya çıkarmaktaydı. Bir yandan, makalenin geri kalanında gösterileceği gibi, doktorlar, devletin ÜYT’ye dair düzenlemelerinin eşik bekçiliğini yapıyordu (Inhorn, 2004) ${ }^{16}$, diğer yandan ise, böylesi düzenlemeler, devletin pronatalist politikaları sonucu ortaya çıkan ve her resmi olarak evli heteroseksüel çifti 'en az üç çocuk' yapmaya davet edip makul vatandaş modelini kadın bedeni üzerinden kuran üreme düzenlemeleri ile çelişiyordu. Fakat, merkezine kadını alan ulusal nüfus politikaları ile yine kadını merkezine alan, onun bedeni üzerinden nüfus mühendisliğine giden ve tahakküm kuran mikro düzey politikalar kadını araçsallaştırmaları açısından çok da birbirinden ayrışmıyordu.

\footnotetext{
${ }^{16}$ Marcia Inhorn (2004), "Privacy, privatization, and the politics of patronage: ethnographic challenges to penetrating the secret world of Middle Eastern, hospital-based in vitro fertilization" isimli çalışmasında, özellikle yaşadığımız hastane ve kliniklerin özelleştirildiği dünyada, doktor, hastane ve klinik çalışanlarının hem klinik ve hastanelerin içsel kültürünü, yapısını ve dinamiklerini değiştiren güçlü aktörler olduğunu hem de etnografik araştırmalarda araştırmacıların mekana ve verilere erişiminde rol oynayan merciler olarak önemli aracılar, eşik bekçileri [gate-keepers] olduklarını söyler. Kendi çalışmamda, gate-keepers terimini hem Marcia Inhorn'un kullandığı gibi, hem de biraz daha genişleterek, doktorların ve hastanelerin devletin üremeye dair düzenlemelerinin uygulanıp uygulanmadığını gözetleyen denetim mekanizmaları olarak da konumlanıp, düzenlemelerin eşik bekçiliğini yaptıklarını tartışıorum.
} 
Devlet Tarafindan Düzenlenen Üremeye

Hastanenin kısıtlı imkanları, sağlıkta dönüşüm, neoliberalizm, devletin üremeye dair düzenlemeleri ile doktorların eşik bekçileri konumu Kürt kadınlarının üremeye dair deneyimlerini Kürt olmayan kadınlarınkinden ayrıştırıp farklı şekillerde etkileyerek, üreme ile ilgili kaynaklara erişimlerini daha da tabakalaştırmaktadır. Makalenin ilerleyen kısımlarında da gösterileceği gibi, patriarkal sistem kadını infertilite tedavisi aramak zorunda olan birincil kişi olarak konumlandırırken, yapısal eşitsizlikleri derinleştiren sosyo-ekonomik ve politik etmenler kadın bedeni üzerinden üremeye dair yeni anlayışlar empoze etmektedir. Üremeye dair kararları, olasılıkları ve deneyimleri etkileyen bu karmaşık sistem, aynı zamanda demografik sürece dair bilgiler verip, genel nüfus verilerinin mikro düzeyde nasıl şekillendiği üzerine de içgörü sağlamaktadır.

\section{5. ÜREME TEKNOLOJILERINE DAÍR DEVLET DÜZENLEMELERININ YEREL SOSYOPOLITIK TARİH İLE KARŞILAŞMALARI}

Bireylerin üreme ile ilgili deneyimleri, uluslararası üreme sağlığı literatüründe siyah feminizm tartışmalarıyla öne çıkan "üreme adaleti” ve kesişimsellik kavramları üzerinden daha iyi anlaş1labilmektedir (Crenshaw, 1991; Ross \& Solinger, 2017). Üreme adaleti kavramıyla, kişilerin sadece çocuk doğurma/doğurmama hakkına değil, aynı zamanda, bireylerin üreme ile ilgili kaynaklara güvenli ve eşit şekilde ulaşımına vurgu yapılarak, devletlerin üreme adaletini sağlayıp işleyebilirliğini sürdürmedeki rolünün altı çizilmiştir. Bu bağlamda, nüfus ve üremeye dair politikalar ırk, etnisite, sınıf, toplumsal cinsiyet, yaş, sakatlık gibi toplumsal dinamikler ve eşitsizliklerle kesişip, bireylerin üremeyle ilgili deneyimlerini şekillendirmektedir (Chrisler, 2012).

Kadınlar üzerine yüklenmiş bazı yerel inanış ve pratikler (evlenme veya anne olma yaşı, eşler arasındaki yaş farkı, ve iffet/bakirelikle ilişkilendirilen ideolojiler gibi) halihazırda sonuçlarına yine kadınların katlanmak zorunda olduğu cinsiyetleştirilmiş özneler yaratmaktadır (Das, 2000; Friese ve ark., 2006; Parla, 2001). Evlilik sonrası, bu inanış ve pratikler kişinin infertil olma dereceleriyle buluştuğu zaman, kişiler farklı kurum ve yapılanmaların - toplum, aile, hastane ve hastane çalışanları gibi - neden olduğu sayısız zorluklarla karşılaşabilmektedirler. Devlet fonu için belli bir yaş aralı̆̆ belirleyen ve infertilite 
Devlet Tarafindan Düzenlenen Üremeye

tedavisinde evli olma koşulunu arayan ÜYT düzenlemelerinin Kürt kadınlarının içinde bulunduğu yaş ve evliliğe dair inanış, pratik ve sosyopolitik tarihle karşılaşması eşit olmayan, çoklu üreme deneyimleriyle sonuçlanmaktadır. Takip eden bölümler gerçekleştirilen etnografik araştırmadan örneklerle böylesi karşılaşmaların nasıl sonuçlar doğurabileceğini ve ne tür (yeniden) düzenlemeler, üremeye dair kararlar, müzakereler ve öznelliklere yol açabileceklerini göstermektedir.

\subsection{Yaş ile İlgili Algılar ve Üreme Politikalarının Yaşa Dair Düzenlemeleri}

Araştırmam süresince, yaşa dair toplumsal alg1 ve pratiklerin hem Kürt hem de Kürt olmayan görüşmecilerimin üremeye dair karar ve deneyimlerini önemli ölçüde etkilediğini gördüm. Fakat, farklı veya daha fazla yapısal eşitsizliklere maruz kaldıkları için, Kürt görüşmecilerimi böylesi algı ve pratikler eşit olmayan şekilde ve daha derinden etkilemekteydi. Diyarbakır'lı, Kürt asıllı, 26 yaşında olan Fatma ve ailesi ile olan anekdotlar yaşa dair alg1 ve pratiklerin kadınların üremeye dair deneyimlerinin nasıl şekillenebileceğini örneklendirecek niteliktedir ${ }^{17}$. Fatma, bana sık sık, evlilik ile ilgili fikir ve 'hayaller'inden bahsederdi. Kendi ve ailesinin tabiriyle 'evlilik yaşı gelmiş' Fatma’nın 'doğru adam' tanımını tartışırken, yaşa dair toplumsal algıları da içine katarak, şunları söyledi:

Benden küçük biriyle evlenmeyi hiç istemem. Ne o öyle! Çocuk yetiştiriyormuşum gibi. Adamın anası gibi gözükmek istemiyorum. Hem genç olunca erkekler seni daha çok arzuluyorlar. Yoksa gözleri dışarı kayıyor. (Alan araştırması notları, Diyarbakır, Bahar 2017)

Fatma’yı tanıyanlar, Fatma’yı önce güzelliğiyle anarlardı. Onlar için Fatma, 'manken gibi bir kız'dı. Fatma, kendini güçlü, ayakları yere basan, bazı durumlarda, kendi tabiriyle, 'erkeklere meydan okuyan,' hem 'modern' hem de 'aile geleneklerine bağlı' biri olarak tanımlıyordu. Fakat, kendini modern olarak tanımlaması, kendinden küçük bir erkekle evlenmenin toplum içinde ve gelecekteki eşiyle olan ilişkisi

${ }^{17}$ Fatma, Diyarbakır'da kaldığım süre içerisinde babasının kuyumcu dükkanında satış sorumlusu olarak yarı zamanlı olarak çalışmaktaydi. 
içerisinde onu dezavantajlı duruma düşüreceğini düşünmesine engel olmuyordu. Kendinden küçük farazi eşinin 'annesi gibi gözükerek' toplumun yargılamalarına maruz kalmak ve yine, yaşından dolayı eşinin gözünün dışarı kaymasını istemiyordu. Fatma'nın yaşa dair algısı patriarkal sistemin bireylere dayattığı yaş algısından bağımsız değildi. Fatma ayakları yere basan güçlü bir birey olup, kendini 'modern' olarak tanımlasa da kendisi dışında, kendini de içine alarak tanımlanmış 'ideal eş' ve 'ideal kadın' kategorilerine uyması gerektiğini düşünüyordu. Birçok Kürt birey gibi, Fatma’nın modernliği tam da bu ilişkiselliğin arasında yer alıyordu. Fatma'nın çiftler arasındaki yaş farkına dair algısı hem aile içi hem de toplumsal dinamikleri kapsayan türdendi.

Fatma'nın ailesiyle ilk tanışıklığım 2017'nin Ocak ayında oldu. Fatma'nın annesi Nur ve babası Salih kendilerini ‘modern', 'okumuş’ ve 'açık görüşlü’ olarak tanımlıyorlardı. Fakat, Fatma ile yukarıdaki konuşmayı yaptığımız sıralarda, Fatma'nın abisi Hani ${ }^{18}$, kendisinden beş yaş büyük bir arkadaşı Deniz'le $^{19}$, bugünkü genel tanımıyla, çıkmaktaydı. Deniz'in de benim gibi o sıralarda Amerika'daki doktorası devam etmekteydi. Deniz, başlarda Hani'ye karşı, kendi tanımıyla, 'ciddi duygular' beslemiyor olsa da Hani'nin ailesi ile tanışması ve hep birlikte sık zaman geçiriyor olmaları, Deniz'in 'kendini aşık olmuş olarak bulmasına' neden olduğunu söylemişti. Deniz, Hani’nin ailesi ve arkadaşlarıyla zaman geçirirken, Fatma ile de yakın arkadaşlık geliştirmişti. Öyle ki, başlarda Deniz ve Hani'nin romantik birliktelikleri olduğunu bilen tek aile bireyi Fatma'ydı. Hani, başlangıçta Deniz'in yaşını 'sorun etmiyor' olsa da, Deniz'in ciddi düşündüğünü anladığında 'yaş' ilişkilerinde sorun haline gelmeye başladı. Hani, kendince durumu şöyle özetlemişti bana:

Deniz'in yaşını kafaya taktım çünkü toplum ne diyecek bilmiyordum. Deniz'i arkadaşlarıma ve aileme tanıştırdım, ama yan yana durduğumuzda yaş farkımız belli oluyordu. Buralarda iyi karşılanmıyor böyle şeyler. Ama, bu Deniz'le ilgili bir şey değil, toplumla ilgili bir şey. Deniz’le

\footnotetext{
${ }^{18}$ Hani, üniversite mezunu, 27 yaşında, ve esnaf.

${ }^{19}$ Deniz, 32 yaşında, doktora yapan Kürt asıllı bir kadın.
} 
çok iyi anlaşıyoruz. Yani bu kişisel değil. Onun kişiliği ile ilgili bir şey de değil. Toplumun, düşüncelerimi nasıl şekillendirdiği ile ilgili bir şey. Zaten babam onunla tanıştırdığım kızların hepsine bir kulp takıyor. Yok ‘bu kısa; bu güzel değil; bu karadır; bunun yaşı çok’ gibi şeyler... (Alan araştırması notları, Diyarbakır, Bahar 2017)

Hani, özellikle babasının tepkisinden çekindiğini söylüyordu. Deniz ise önceleri bu gelişmelerden habersizdi. Deniz, kendilerini açık görüşlü ve modern olarak tanımlayıp bunları kendilerince performe eden, aynı sofraya oturduğu bir ailenin Deniz'in yaşıyla ilgileneceğini düşünmüyordu. Sonradan anladım ki, aslında Deniz’in yaşını Hani’nin ailesi de bilmiyordu. Hani, ciddi düşüneceği kişinin daha genç bir bedene sahip olmasını arzularken, Deniz'in yaşı ev içinde konuşulan bir konu olmuştu. Her ne kadar Hani, Deniz ile arasındaki yaş farkını 'bariz’ olarak yorumlasa da onları tanıyanların çoğu yaş farkını görmüyorlardı. Fatma’nın anlattıkları bunu özetler nitelikte.

Bir gün, babaları olan Salih amca, Hani’ye, yaşından dolayı Deniz ile olan birlikteliklerini onaylamadığını söylemiş. Fatma, hemen araya girerek, "O kadar da yaşlı değil, bir ya da iki yaş var aralarında!" diye cevap vermiş. Hani ise, çekinerek, "Yok, aramızda beş yıl yaş farkı var," demiş. Fatma, buna şaşırmış da olsa, "Ne olacak, sanki kız 40 yaşında! Çocuk yapabilecek yaşta." Her ne kadar kendisi farklı düşünse de Fatma için Deniz'in yaşı 'kabul edilebilir'di çünkü Deniz hem yaşını göstermiyordu hem de henüz üreme yaşını geride bırakmamıştı. Deniz'in yaşı geniş aile üyeleri arasında da tartışılıyordu. Ailenin bir kısmı Deniz'in yaşını 'umursamazken,' diğer kısmı ise yaş farkının önemli olduğunu söylüyordu. Deniz ve Hani’nin ilişkileri ayrılıkla sonuçlandı. Hani, Deniz’i kendisinden dört yaş küçük olan eski sevgilisiyle aldattı. Deniz'in durumu öğrenip Hani’yle ayrılmasından sonra Hani eski sevgilisiyle bir ilişkiye başladı.

Bu bağlamda, yaş, sadece bir kadının nasıl göründüğü ile ilgili değil (genç veya genç olmayan), aynı zamanda kadının üreme kabiliyeti ile de ilişkilendirilen bir faktör olarak karşımıza çıkmaktadır. Hem kadın hem de erkek için kadının yaşı ve kadın ile erkek arasındaki yaş farkı farklı derecelerde de olsa kaygı nedeni yaratmaktadır. Bahsettiğim bu ilişkisellik, yukarıdaki örnekte de görüleceği gibi hem 
Devlet Tarafindan Düzenlenen Üremeye

doğrusal hem de doğrusal olmayan yollarla kurulabilmektedir. Yani, 'genç olmak' çocuk sahibi olabilmenin habercisi olarak algılanabilirken, çocuk sahibi olmak (olmaya devam etmek) 'gençlik' ile ilişkilendirilebilir. Alan araştırması süresince tanıştığım kadınlar, yaşla birlikte biyolojik sınırlamalarının da arttığını düşünerek kendilerini, kendi tabirleriyle, 'bizden geçmiş' veya 'işe yaramaz’ olarak tanımlayabilmekteydiler. Bu yüzden, üreme söz konusu olduğunda, yaş ve yaşa dair uygulama, pratik ve inanışların kendi toplumsal ve tarihsel bağlamları içerisinde düşünülmesi gerekmektedir.

Farklı sosyoekonomik ve politik bağlamlarda, global bir fenomen olarak görülen bilim (Rapp, 2006), yaşa ve evliliğe dair ulusal düzenlemeler, yerel inanış ve pratiklerle karşılaştığında çeşitli üreme deneyimleri ortaya çıkarmaktadır. Sonraki analizler üremeyle ilgili deneyim ve kararların öznellikler, bilim, tarih, sosyo-ekonomi ve politikalarla karşılaştığında ne tür şekiller alabilecekleri ve genel demografiyi nasıl etkileyebilecekleri üzerinedir.

\subsection{1. 'Kimlik Yaşım Doğru Değil': Sosyopolitik bir gerçeklik olarak doğum tarihleri}

Kadınların yaşla ilgili kaygıları sadece toplumsal olarak değil, aynı zamanda devletlerin yaşı temel alarak üremeyi düzenleme yöntemleriyle de şekillenmektedir. Problem üreme ve üreme için sağlanan parasal destek olduğunda, devletler ÜYT ödeneği için kadınlara yaş sınırlaması getirebilmektedirler. Sosyoekonomik olarak şekillenen yaşa dair kaygılar, ÜYT desteğinin (araştırmayı gerçekleştirdiğim sırada) 39 yaş ile sınırlamaları, düzensiz kayıtlandırılmış kimlik kartları ve kadınların eşleri tarafından desteklenmemesi ile birleştiğinde, yaşla ilgili endişeler getirecekleri sonuçlardan dolayı daha fazla artmaktadır ${ }^{20}$. Aşağıda verilen anekdot, Diyarbakır devlet hastanesinde karşılaştığım infertilite tedavisi için hastaneye gelen kadınlardan birine aittir. Bu anekdot, yaş ile ilgili düzenlemelerin diğer etmenlerle kesişmesi sonucu daha ileri korkular yaratıcığına örnek teşkil etmektedir. 
40 yaşındayım. Kimlikte 44, ama yanlış o... Beş aydır evliyim. Gereken bütün testleri yaptırdım ama kocam muayeneye gelmiyor... Çok korkuyorum çocuğum olmayacak diye. Yaşım da geçiyor. (Alan araştırması notları, Diyarbakır 2017)

Deniz ve Hani örneğine paralel olarak, yukarıdaki anekdot kadınların üreyebilme kabiliyeti ile ilişkilendirilen yaşa dair kaygıların evlendikten sonra da günlük yaşamlarını işgal etmeye devam ettiğini göstermektedir. Yaşla ilgili kaygılar, maddi yetersizlik, ailesel ve toplumsal destek yokluğu, eşit ve hassas olmayan belgelendirme ile birleştiğinde kadının yükü ve tasaları daha da artmaktadır. Doğru olmayan doğum kayıtları üreme eşitsizliğini körükleyen önemli elementlerden biri olarak karşımıza çıkmaktadır. Yukarıdaki örnek, Diyarbakır'ın devlet hastanesinde sıklıkla karşıllaştı̆̆ım yaşa dair kesitlerden sadece birisi. Kadınların, çocuk sahibi olamama ve çocuk sahibi olma gerekliliği kaygısını tek başlarına omuzlamış oldukları durumlarda, devletin kadınların (kimlikte doğru kaydedilmemişs) yaşlarından dolayı infertilite tedavisini karşılamaması bazı kadınları çaresiz bırakmaktadır. Takip eden etnografik kesit, bunu, içine kattığı aktörlerle birlikle, güncel, sosyopolitik ve tarihsel konumsallığının kesişimi bağlamlarıyla açıklamaktadır.

Hasta kabul formunu dolduran hemşire, odada bulunan hastaların yaş, evlilik durumu gibi temel bilgilerini aldıktan sonra, hastalara hemen bitişik masamızda oturan Doktor Bey'e muayene olmak üzere sıraya girmelerini söylüyordu. O sırada sadece beyaz bir perde ile odayı ayıran muayene odasından çıkan Doktor Bey eldivenlerini çıkarıp bilgisayarının başına otururken, içerde giyinmekte olan hastaya seslenerek, 'Yaşın kaçtı senin' diye sordu. '37,' diye cevap verdi kadın. Bunu duyan hemşire, doktora hızlıca bakarak aceleyle hasta kabul formlarını karıştırmaya başladı. Hemşire, üzerini düzelterek muayene odasından çıkan hastaya, "Sen 37 değilsin, 43 yaşındasın, neden yalan söylüyorsun?" diye çıkıştı. Kadın, biraz da şaşırarak, “Ama o benim gerçek yaşım değil. Babam, kardeşim askere geç gitsin diye benim yaşımla benden büyük olan erkek kardeşimin yaşını değiştirmiş," dedi. Doktor, dudağını bükerek, "Sebebi çok da fark etmiyor, kimlikteki yaşın önemli. Kimlik yaşın 39'dan büyük olduğu için sigorta tedaviyi karşılamaz,” diye cevap verdi kadına. (Alan araştırması notları, Diyarbakır, Kış 2017) 
Kimlik kartları, Kürt kadınlarının günlük yaşamlarını şekillendirip, kimlerin ÜYT ödeneğine erişip erişemeyeceğine karar verirken, aynı zamanda sosyopolitik tarihlerinin hikayelerini de anlatarak, üremeye dair eşitsizliklerin nasıl daha fazla körüklenebileceğini gösterir. Helga Tawil-Souri (2011), İsrail devletinin Filistinlilere uygulamış olduğu farklı kimlik kartı uygulamalarını inceleyen makalesinde, kimlik kartlarının devlete gözetleme olanağı veren modern teknolojik araçlardan olduğunu söyler (Tawil-Souri, 2011, s. 73). Bu bağlamda, kimlik kartları bir yandan toplumun sosyal kompozisyonunun yönetilip düzenlenmesine olanak sağlarken, diğer yandan yapısal eşitsizlikleri hem temsil eder hem de sürdürülmesine vesile olur. Başka bir ifadeyle, kimlik kartıyla ilgili düzensizlikleri teşvik eden düzensizlikler, bugün üremeyle ilgili düzenlemeler yoluyla kadınların bedenlerinde, hayatlarında üreme eşitsizlikleri yaratarak tekrar canlanmaktadır.

Yönetimsel araçlardan yalnızca biri olan kimlik kartlarının fiziksel varlı̆̆ının temsiliyetlerine ek olarak, kimlik kartı üzerinde olan bilgiler de kişilerin hayatlarını derinden, hatta hayati derecede etkilemektedir ${ }^{21}$. Kadınların sosyo-ekonomik ve psikolojik iyiliklerinin çocuk sahibi olma derecesiyle ilişkilendirildiği bir toplumda, üreme haklarından kendi sosyopolitik tarihlerinden dolayı mahrum edilme, kadınları daha fazla dezavantajlı olan bir yere hapseder. Sosyopolitik tarih hem daha önce bahsetmiş olduğum çatışma ortamında yaşamayı ve hayatı devam ettirme çabalarını kapsadığı gibi, çatışma bölgesinde yaşamanın kendisinin neden olduğu farklı, fakat kendine özgü yapısal eşitsizliklerin patriarkal sistemle kesişimine işaret etmektedir. Türkiye'de yapılan bir çok çalışma, etnik konumlarından dolayı ortaya çıkan yapısal eşitsizliklerin, diğer etnik gruplarla karşılaştırıldığında, Kürt kadınlarını eşit olmayan bir şekilde daha fazla etkilediğini ve kaynaklara erişim ve kullanımını

\footnotetext{
${ }^{21}$ Başka yerde bahsettiğim gibi, yıllar süren PKK ve Türkiye arasındaki çatışmalar, Türkiye'yi iki etnik grup olan ‘Türk’ ve 'Kürt' etnik kampa ayırdığı için, Kürt kadınlarının kimlik kartları üzerinde var olan 'doğum yeri' gibi bilgiler onları ırksallaştırıp (politik Kürt), sağlıkla ilgili mekanlarla ayrımcılığa uğramalarına, hatta, bazı durumlarda, tedavi ve kontrollerinin reddedilmesine neden olabilmektedir. Bkz: Kilictepe, Safak. "Feeling like a 'Misfit': Kurdish Women's Entangled Reproductive Experiences in Turkey." Hilal Alkan, Ayse Dayı, Sezin Topçu, Betül Yarar (Ed.). The Politics of the Female Body in Contemporary Turkey içinde Çıkacak (2021).
} 
Devlet Tarafindan Düzenlenen Üremeye

kısıtladığını ortaya koymaktadır (Gündüz-Hoşgör \& Smits, 2008; Smits \& Gündüz-Hoşgör, 2003; Yavuz, 2005; Zeyneloğlu et al., 2011, 2016).

Aslında, ekonomik olarak dezavantajlı ailelere doğmuş çoğu Kürt kadınının kimlikteki yaşlarının gerçekle ilgisi olmadığını yine Kürt olan bir kaç doktorla konuşmuştum ${ }^{22}$. Erkek kardeşleriyle yaşlarının değiştirilmesine ek olarak, ulaşım araçlarının olmadığı ve şehir merkezine yolculuğun neredeyse imkansız olduğu köylerde yaşayan, Türkçeyi ya hiç bilmeyen ya da iyi konuşamayan ve devlet memurlarıyla iletişim kurmanın zorluğunu yaşayan babaların, şehre indiklerinde ‘ $3-5$ çocuğunun' yaşını hep birlikte kaydederek, hepsine neredeyse aynı yılı veya bir yıl aralıklı yaşlar verdiklerinden de bahsetmiştik. Şehir merkezine uzaklık, aynı dili konuşamıyor olma engeli, zamana dair algıların modern hayatla uyumsuzluğu da kadınların yaşlarının kimlik yaşlarından faklı olmasına neden olup, kadınların sağlıkla ilgili kaynaklara erişimini sınırlandırmaktadır. Fakat, özellikle devlet çalışanı olan doktorlar sosyoekonomik ve politik tarih ile kimlik kartları arasındaki ilişkinin farkında olsalar da devlet çalışanı olma konumlarından dolayı, onların gözünde kadınların kendi hikayesinin hiç bir ağırlığı kalmamaktadır. Nihayetinde, devletin üremeye dair düzenlemeleri ve doktorların devlet çalışanı olma konumları, sahip oldukları bilgiye yeniden biçim vermektedir: kimlik kartı yaşı esastır! Böylesi karmaşık olan üremeye dair karşılaşmalar kadınların sosyoekonomik durumlarına bağlı olarak (daha fazla) çocuk yapmak konusundaki kararlarını etkileyebilmektedir. Başka bir deyişle, yaşlarından dolayı devletin infertilite tedavisi ödeneğinden yararlanamayan kadınlardan ekonomik imkânı olanlar masraflarını ceplerinden ödeyebiliyorken, imkanları olmayanlar ise medikal çözüm arama yollarını terk etmek zorunda kalabilmektedirler. Yani, üremeye dair olasılıkların ve kararların ekonomik gelirle iç içe geçtiği böylesi durumlar ve sosyopolitik tarihle üremeye dair düzenlemeler demografik süreci derinden şekillendiren bağlamlar olarak karşımıza çıkmaktadır. Diğer bir deyişle, eşit gözüken bir uygulama ÜYT ödeneğinin T.C. vatandaşları için 23 ve 40 yaş aralığıyla sınırlandırılması - ekonomik ve patriarkal

22 İlk defa duyduğum bir bilgi değildi bu. Hem ailemde hem de çevremde kimlik yaşlarının yanlış olduğu, hatta gerçek yaşlarını ebeveynleri de dahil kendilerinin bilmediği birçok insan var. 
sistemdeki yerleriyle kesişip Türkiye'de yaşayan Kürtler arasında üremeye dair eşitsizlikler yaratmakta ve kadını daha da müşkül konuma itebilmektedir. Bu eşitsizliklerin temellerinden biri sosyopolitik tarihin kimlik düzenlemelerine yansımasıdır. Örneğin, babalar erkek çocuklarının 'erken yaşta' zorunlu olan askerliklerinin önüne geçmeyi amaçlarken, Kürt kadınlarının yaşları ve kimlikleri erkek kardeşlerininkinin ağırlığı altında kalmıştır. Sistemsel bir zorunluluk olan erkeklerin askerlikleri ve askerlik ile ilgili düzenlemeleri kasıtsız sonuçlar ortaya çıkarak, kadınların bedenlerini ve arzularını ihlal etmektedir. Gerçekte, kadının refahı erkeğinkine feda edilmektedir. Böylesi bir sistem erkeğin geleceğini kadının geleceğinden daha imtiyazlı kılarak, ata soylu kültürü kadınların kimlik kartları üzerinden ve medikal sistemle yeniden üretmektedir.

\subsection{Evlilik Durumu}

Resmi evlilik içinde olma infertilite tedavisinin ön koşuludur. Hem Ankara'da hem de Diyarbakır'daki bulunduğum özel ve devlet hastanelerinde ÜYT yoluyla tedavi olmak isteyen ve olmas1 gereken hastaların evlilik cüzdanları tedaviyi alacakları kurumlar tarafından istenip, kopyalanıp hastaların dosyalarına eklenerek, hizmet alan hastaların evlilik durumları arşivlenmekteydi. Sağlık Bakanlığı, tedavi alan çiftlerin evli olup olmadıklarını sıkı bir şekilde denetler ve eğer hastanelerin arşivlemeyi güvenilir ve sistemik bir şekilde yapmadıklarını tespit ederse, bu hastaneler kapatılabilir.

Fakat, özellikle Diyarbakır'da hastaneye gelen infertilite hastalarının önemli bir oranı sadece imam nikâhlı evlilikler içerisinde olup, resmi evlilik cüzdanı edinmemişlerdi. Hastane çalışanları hastaları infertilite tedavisinin 'evlilik şartı' konusunda bilgilendirip, onlara evlilik cüzdanlarıla geri gelmelerini söylüyorlardı. Ancak, hastane çalışanları için infertilite tedavisinde, onların deyimiyle, 'basit' gözüken evlilik ön koşulu, çiftler için hali hazırda, kendi deyimleriyle, 'zor' ve 'çetrefilli' olan infertilite tedavi sürecini daha da karmaşıklaştırabiliyordu. Mesela, Diyarbakır'daki özel hastanede görüşme yaptığım infertilite tedavisi alan çiftlerin büyük çoğunluğu, tüp bebek tedavisine yüklenen olumsuz anlamlar, yanlış algılardan dolayı - tüp bebeği haram görme, başkasının çocuğunu alma, başkasının spermini kullanma vs. - ve olumsuz yorumlarla karşılaşıp daha fazla baskı görmemek için tüp bebek yaptıklarını 
en yakınlarından bile saklıyorlardı. Yani, resmi evlilik şartı bazı çiftler için ya mümkün değildi ya da onlar için işleri daha da zorlaştırmaktaydı. Resmi evlilik şartını yerine getiremedikleri için bazı hastalar tedaviden vazgeçmek zorunda kalıyorlard1, ki bu da üremeye dair ulusal düzenlemelerin yerelde kişilerin üreme yollarına erişimini sınırlandırıp, demografik sürece kesin bir yön verdiğini göstermektedir.

Heteroseksüel evlilikler Türkiye'de yasal olarak tanınan tek evlilik türü olmasına rağmen, resmi evlilik oranı, Türkiye'nin diğer bölgeleriyle kıyaslandığında, Doğu ve Güneydoğu Bölgelerinde çok daha düşük olduğu görülmektedir ${ }^{23}$. Bu bölgelerde, yaygın bir şekilde, birincil olarak tanınan evlilik türü ise dini evlilik veya imam nikahı olarak adlandırılan evlilik türüdür (Civelek ve Koç, 2007; Turgut vd., 2015). Yaprak Civelek ve İsmet Koç’un (2007) yaptıkları bir çalışmaya göre, sadece dini nikah oranlarının en yaygın olduğu bölgeler Doğu Anadolu ve Güneydoğu Anadolu Bölgeleridir. Bu tür evlilikler devlet dökümanlama sistemine girmedikleri için evliliğe dair istatistiklerde yer almazlar. Dini nikahın resmi düzeyde tanınmıyor oluşu ise yalnızca dini nikahla evlenen bireylerin infertilite tedavisi arayışında problem olarak karşılarına çıkmakta ve üreme ile ilgili kaynaklara erişimini sınırlamaktadır. Bu durum, kuma olarak çoklu bir evliliğin içerisinde olan kadınları çok daha fazla etkilemektedir. Yani, ÜYT kullanımında resmi evlilik şartı gibi bir devlet düzenlemesi özel alanı da düzenlemekte, üremeye dair deneyim ve kararları yeniden şekillendirmektedir.

\subsection{1. Çok Eşlilik, Kumalık ve Demografik Süreç}

Diyarbakır'daki görüşmecilerimin bazılarının birden fazla annesi vard ${ }^{24}$. Bazıları, biyolojik annelerinin babalarıyla resmi nikahı olmadığından, biyolojik annelerinin üzerine kayıtlı değillerdi. Bunun yerine, babaları hangi anneleriyle resmi evlilik yapmış ise resmi kayıtlarda onların çocukları olarak

\footnotetext{
${ }^{23}$ Bkz, "Diyarbakır'da Evlilik Oranları Arttı, Boşanmalar Azaldı”, Pasurun Sesi, 3 Mart, 2016. 4 Şubat, 2018 tarihinde erişildi. http://www.pasurunsesi.com/haber/3196/diyarbakirda-evlilik-oranlari-artti-bosanmalar-azaldi.html

${ }^{24}$ Çoklu evliliklerin oranı Türkiye'de düşüyor olsa bile özellikle Güneydoğu ve Doğu Anadolu Bölgelerinde göreceli olarak daha yoğunlukla sürdürülen bir pratik olmaya devam etmekte. Van'da yapılan bir çalışma, kadınların \%11.3'ünün çoklu evlilik içerisinde olduğunu göstermektedir (Gücük vd., 2010). Bu kadınlardan bazıları ise resmi evlilikleri olmadıkları için resmi kayıtlarda hala evlenmemiş olarak gözükmektedirler.
} 
gözüküyorlardı. Bu durumu problem olarak görmedikleri halde, çoklu evlilik pratiğinin de geçmişe oranla daha az sıklıkta gerçekleştiğini vurgulamışlardı. Fakat, pratiğin az olması veya azalması, pratiklerin kendilerinin demografik sürece katkıda bulunduğunu görmezden gelmemize neden değildir. Aksine, Skinner'in de tartıştığı gibi (1997), demografik süreç, aslında, aile içerisindeki böylesi dinamikler sonucudur.

Görüştüğüm kadınlar, kumalığı arzu etmedikleri halde, çoklu evlilikleri evlilik türlerinden biri olarak görmekteydiler. Kumalık sistemi içerisinde olup resmi evliliği olan kadınlar çoğunlukla eşleriyle 'ya ilk evlenen' ya da 'ilk (erkek) çocuğu doğuran kadın' konumundaydılar. Resmi olmayan evlilik içerisinde olan kadınlar, özellikle çocuk sahibi veya erkek çocuk sahibi olamadıklarında, boşanma, üstüne kuma getirilme, baba evine gönderilme gibi durumlarla karşı karşıya kalarak, sosyo-ekonomik durumları ve aile içerisindeki konumları sarsıntıya uğramaktadır. Böylesi bir patriarkal sistemde, çocuksuzluk söz konusu olduğunda ÜYT 'kurtarıcı' olarak görülse de, bazı kadınların etnik, sınıfsal ve toplumsal cinsiyet kimliklerini göz ardı eden ÜYT düzenlemeleri hem ÜYT’ye erişimin kendisini hem de ÜYT'den geçme sürecini farklı aktörleri içine alarak karmaşıklaşmaktadır. Diyarbakır'da özel bir tüp bebek hastanesinde tanıştı̆̆ım Ceylan'ın yaşadıkları bu karmaşıklığı örnekler niteliktedir.

Ceylan, 40 yaşını yeni aşmıştı. Tüp bebek tedavisi için Şanlıurfa'dan gelmiş olan Ceylan, aşiret geleneklerine sıkı sıkıya bağlı bir ailedendi. Babası Ceylan'ı, Ceylan'ın mühendis olan amcasının oğluna 'gelin diye vermişti.' Fakat, Ceylan'ın uzun bir süre çocuğu olmadığı gerekçesi ile Ceylan'ın eşi başka bir kadınla (imam nikahıyla) evlenmiş. Zaten çocuğu olmadığı için evde hem psikolojik hem de fiziksel şiddete maruz kalan Ceylan'ın evdeki konumu, kumasının çocuk sahibi olmasıyla daha fazla sarsılmış. Görüşmemiz sırasında, Ceylan evdeki konumunu, "Benim yerim evdeki hayvandan da sonra geliyor," diye tanımlamıştı bana. O zamanlar henüz üniversite öğrencisi olan Ceylan'ın görümcesi Ceylan'ın uğramış olduğu kötü muameleye dayanamayarak, Ceylan'ı alan araştırması yapmış olduğum özel hastaneye getirmişti. Fakat, o zamanki giderleri yaklaşık 8.000 TL civarı olan hastane masraflarını, eşi hiçbir destek sağlamadığı için, kendisi karşılamak zorunda kalan Ceylan, hastaneye gelmek için 
Devlet Tarafindan Düzenlenen Üremeye

elinde ne var ne yoksa satmak zorunda kalmıştı. Ceylan, o evde insan yerine koyulmak için tüp bebeğin son çaresi olduğunu söylüyordu. 'Gelinlikle girdiği evden ancak kefenle çıkabilecek' Ceylan'ın ‘baba evine dönmek’ gibi bir şansı da yoktu. Bütün umudunu elindeki her şeyi satarak tüp bebeğe bağlamıştı. Maalesef tüp bebek Ceylan için olumlu sonuçlanmadı. Ceylan'dan bir daha haber alamadım. Zaten yalnız girmiş olduğu başarısız olan tüp bebek sürecinden sonra evde nelerle karşılaştı bilmiyorum. Fakat, Ceylan üniversite öğrencisi olan görümcesi sayesinde, eşini de sperm vermek için 'ikna etmeyi' 'başararak' tüp bebek tedavisine başvurabilmişti. Tedavinin başarılı olup olmaması ise demografiyle ilgili istatistiklere ' +1 ' veya ' 0 ' olarak yansıması demekti. İşte demografik verilere neden olan demografik süreç aslında Ceylan gibilerinin geçmiş olduğu üreme deneyimlerinin bir sonucudur. Bu makalede geçen deneyimler ise onların sayılardan daha büyük olduğunu, sosyo-ekonomik ve politik alana dair çok daha fazla bilgi verdiğini göstermektedir. Kadın bedenini toplumsal olanın kapsamı olarak düşündüğümüzde, onun bulunduğu etnik, sınıf ve toplumsal cinsiyet bağlamları açısından farklı hiyerarşik iktidar ilişkileri içerisinde farklı derecelerde konumlandıklarını daha açık bir şekilde görmekteyiz (Kutluata, 2002). Kadınlar farklı hiyerarşik sistemleri içinde farklı ayrımcılıklara ve ezilmişliklere maruz kalırlar. Yani, kadın bedeninin ata soyluluğun devamı için araçsallaştırılıp nesnelleştirildiği, üreme üzerinden tahakküm sağlandığı bir kontekste, çocuk sahibi olmak kadının toplum içindeki sosyo-ekonomik konumunu iyileştiren olgulardan biri olarak karşımıza çıabilmektedir. Başlı başına, bu durum ise, kendi içerisinde yeni eşitsizlik ve hiyerarşik ilişkilere yol açıp, üreme adaletsizliğini tâbi kılmaktadır.

Örneğin, çocuksuzluk söz konusu olan bazı durumlarda, kadınlar eşlerini (bazı görüşmecilerimin deyimiyle) 'kendi elleri’yle boşayıp, kendilerine (eşleriyle resmi evliliği olacak) kuma getirilmesini isteyebiliyorlardı. Bunu, kendilerinin yerine getiremediği 'görevi' başka kadın yerine getirebilsin ve 'kocaları çocuk sahibi olup soylarını sürdürebilsin' diye yapıyorlardı. Necla, bu kadınlardan yalnızca birisiydi. Ev hanımı olan Necla, 40 yaşlarındaydı ve Diyarbakır'ın Bismil ilçesinin köylerinden birinde yaşıyordu. Evlilikten birkaç yıl sonra çocuğu olmayınca, 'eşinin soyunun devamı için', Necla eşini 
Devlet Tarafindan Düzenlenen Üremeye

boşamış ve başka bir kadınla resmi nikah yaptırmış. Necla, bir süre aynı evde kaldığı kumasının bitmek bilmeyen baskı ve küçümsemelerine maruz kalmış. Kumasını 'şeytan' olarak tanımlayarak şunları söyledi:

Onlarla yaşamayı denedim ama kumam şeytanın tekiydi. Sonrasında da bu eski eve (kendi evini göstererek) taşındım. Çocukları var şimdi, ama en azından sürekli aşağılanmaktan kurtuldum. (Alan araştırması, Diyarbakır, Bahar 2017)

Bu örnekte, Necla'nın hem evliliği hem de boşanma durumu resmi kayıtlarda yer almıştır. Fakat, Necla kendini boşanmış bir kadın olarak tanımlamadı bana. Kendini hala evli olarak görüyordu, sadece eşi ve kumasıyla birlikte yaşamıyordu. O kadar. Ancak, resmi kayıtlar, Necla'nın boşanmasına neden olan patriarkal meselelere ve dinamiklere dair herhangi bir bilgi vermiyordu. Demografik sürecin nasıl şekillendiğini, Necla'nın eşinin neden başka bir kadınla evlenip ondan çocukları olduğuna dair bir şey söylemiyordu. Kişilerin evlilik ve üremeye dair fikirlerine aslında böylesi iktidar ilişkileri yön verip, şekillendirmektedir. Bireylerin hikayeleri ve hayatlarına yakından bakmak demografik sürecin hikayesine de 1şık tutmaktadır.

Yaşadıkları patriarkal sistem içerisinde ata soyluluğu esas alan ve kadın için resmi evliliği çocuk sahibi olmakla koşullandıran toplumsal şartlar, medikal sistemin evlilik şartıyla karşılaştı̆̆ında kadın için daha da çıkmaz bir hâl alabilmektedir. Tek eşli evlilik içinde olup eşleriyle yalnızca dini nikahla evli olan kadınların bu koşulu farklı yollarla, bazı durumlarda doktorları da içine alarak, müzakere etme şansları varsa bile, kuma olup da eşlerinin diğer bir kadınla resmi evlilik yaptığı koşullarda müzakere yolları neredeyse tamamen tıkanmış olmaktadır. Örnek vermek gerekirse, kuma olarak evlenen Halime, Halime'nin eşinin ilk eşiyle yapmış olduğu resmi evlilikten dolayı sadece dini nikahla evlenmişti. Bir yılı henüz aşmış bir evliliği vardı ama bu süre zarfında hamile kalamayıp evlilikteki konumu sarsıldığı için, hastaneye görünür bir kaygıyla gelmişti. Halime kendisine refakatçi olması için okuma yazması olan yeğenini de getirmişti yanında. Halime'yi öncesinde görmüş olan doktor, Halime'ye eşinin nerde olduğunu sordu. Uzun zamandır, kendi deyimiyle, ‘çocuk tedavisi’ için doktora gelip giden Halime’nin 
eşi doktora görünmeyi hiçbir zaman kabul etmemiş. "Çocuk tedavisi için doktora gelmez o hocam, 'problem sendedir' diyor,” dedi, Halime. O sırada, Halime'nin yeğeni hızlıca araya girerek: "Doktor bey, ama eniştemin önceki evliliğinden çocuğu var. En küçüğü iki yaşında,” dedi. Doktor, Halime'nin yeğenine, çocuk sahibi olduktan sonra da üreme ile ilgili problemler yaşanabileceğini söyledi ve ekledi: “Bu yüzden eniştenin problemi olup olmadığını sonuçlarını görene kadar bilemeyiz.” Halime’nin durumuna ve çaresizliğine üzülen doktor, "Kocası gelmeyen ve evlilik cüzdanı olmayan kadınları muayene etmiyor veya herhangi bir tedavi önermiyorum ama senin durumun çok çaresiz. Elimden geldiği kadar yardımcı olmaya çalışacağım," dedi. Böylece, doktor, overlerinde (yumurtalıklarında) sorun olan Halime’ye overleri düzenleyici ilaç yazdı.

Halime'nin çaresizliği ve korkusu gözlerinden, hal ve hareketlerinden açıkça okunabiliyordu. Halime, hamile kalırsa, kendi deyimiyle, 'kapı önüne koyulmayacaktı.' Fakat, çocuk sahibi olamamanın tam olarak ne tür bir sorun ve kimden kaynaklandığını ve de ilaçların çocuk sahibi olma çabasında işe yarayıp yaramayacağını ne ben, ne Halime ne de doktor biliyordu. Medikal sistemin dayatmış olduğu umudun politik ekonomisi derin hayal kırıklıklarını da beraberinde getirebilirdi (Novas, 2006). Başka bir deyişle, Halime hamile kalmayabilirdi. Fakat, ilaçlar sayesinde hamile kalması ise, Halime'nin 1srarcı ve medikal sistem içerisinde girmiş olduğu müzakereler ile karşısına çıkan doktorun empatisiyle gerçekleşecekti. Halime'nin hamile kalması nüfusa ' +1 ' olarak yansıyacakken, bu sayının meydana gelişi veya gelmeyişi medikal sistemin merkezinde durduğu karmaşık dinamikler, karşılaşmalar ve sistemler Halime gibi diğer Kürt kadınlarının üreme ile ilgili deneyimlerini şekillendirerek nüfus verilerini etkiliyordu.

Halime'nin durumunda, infertilite tedavisine yönelik düzenlemeleri sınırlı da olsa 'bükebilen' doktor, başka hastalarda böylesi bir esneklik göstermiyordu. Bunun nedenleri arasında hem Halime'nin, doktora belirttiğine göre, diğerlerine nazaran daha 'çaresiz oluşu,' hem de ÜYT kullanımı için resmi evlilik koşulundan bağımsız olan Halime'nin over problemi yer alıyordu. Yönetimselliğin ve biyopolitikaların Kürt kadınlarının üremeye dair kararlarını ve deneyimlerini nasıl şekillendirdiğini ve demografik sürece 
Devlet Tarafindan Düzenlenen Üremeye

katkısı bulunduğunu gösteren böylesi örnekler, aynı zamanda yönetimselliğin ve failin sınırlı oluşuna da işaret etmektedir (Gupta, 2012). Sınırlılığın kendisi hem içinde bulunduğu patriarkal sistem hem de biyopolitikalar tarafindan şekillenmiştir. Diğer bir deyişle, resmi evliliği olmamasına rağmen, Doktor Halime'yi muayene edip ona infertilite tedavisinde de kullanılan overleri düzenleyici ilaç yazmayı kabul etti. Yönetimselliğin bir şekli olarak tanımladığım ÜYT düzenlemeleri infertilite tedavisini sadece evli çiftlerle sınırlarken, medikal sistemdeki ‘esneklikler’ yönetimselliğin bükülebilmesine neden oluyordu. Fakat, Halime'nin eşi erkekte sorun olabileceğini kabul etmeyip doktora görünmeyi reddettiği için, doktorun sorunu tam olarak irdelemesini imkansız k1lmaktaydı. 


\section{SONUÇ}

İyi bilinen antropologlardan Nancy Scheper-Hughes (1997), "Sayıları Olmayan Demografi [Demography Without Numbers]" makalesinde, “Göstermek istediğim aslında tekil bir örneğin, bir 'n' in 1 oluşu, demografik araştırmaya katabildiği şeydir," der (Scheper-Hughes, 1997, s. 212). Çalışmalarının önemli bir kısmını Brezilya gibi bebek ve çocuk ölümlerinin yüksek olduğu bir ülkede gerçekleştiren Scheper-Hughes, bazı ölümlerin istatistiklerde yer almadığı için tanınmadığından bahseder ve demografinin tam olarak kavranması için sadece sayılara bakmanın yeterli olmayacağını ve demografik olarak çalışılan toplumların yakından, tercihen etnografik araştırma teknikleriyle incelenmesi gerektiğini söyler. Devlet istatistikleri, üremeye dair devlet düzenlemelerinin farklı gruplara ait bireylerin üremeyle ilgili kararlarını, seçimlerini ve müzakere yollarını nasıl şekillendirdiği konusunda bilgi vermemekle birlikte genel nüfusa nasıl katkıda bulunduğuyla ilgili de veri sağlamakta yetersiz kalmaktadır. Üremeye dair makro ve mikro düzenlemeler, kadın bedenini genel bir kategori olarak görmekte, kadının sosyopolitik tarihini ve içinde konumlandığı farklı kimlikleri (etnisite, sınıf, toplumsal cinsiyet gibi) yok sayıp, onun bedeni üzerinden otoritesini meşrulaştırmaktadır. Bu makale, demografik çalışmalar yapılırken görmezden gelinen mikro düzey dinamiklerin sayıları ve demografik süreci nasıl şekillendirdiğini, istatistiklerin bütün deneyimleri ve hayatları yeterince ele almadığını, hatta bazı durumlarda görmezden geldiğini göstermektedir. Üreme ile ilgili deneyimler ve kararlar, bu ‘önemsiz’ gözüken kamusal, sosyal, özel ve mikro düzeyde gerçekleşen pratikler ve devingenler olup demografik süreci önemli derecede etkilemektedir. $\mathrm{Bu}$ makale, demografiye dair rakamsal ve istatistiksel analizler sunmamaktadır. Fakat, hem demografi verilerinin Türkiye'de yaşayan diğer guruplar açısından farklılık göstermesi hem de sosyopolitik tarihlerinin onları diğer gruplardan ayrı kılması açısından, Kürt kadınlarının üremeyle ilgili deneyimlerine odaklanarak, bu makale, demografik sürecin (evlilik, boşanma, doğum oranları gibi) üreme teknolojileri ve çoklu olan karmaşık iktidar ilişkileri tarafından nasıl şekillendiğini göstermiştir.

Bilim (ÜYT, bu makaledeki bağlamında) ve bireyler arasında ortaya çıkan karşılaşmalar yönetimselliğin, biyopolitikaların, patriarkal yapının, cinsiyet ve aileye dair yerel inanış ve pratiklerin 
Devlet Tarafindan Düzenlenen Üremeye

ürünü olarak demografik sürece yön vermektedir. Böylesi karşlaşmalar hem yeni özneleri ve uzlaşma yollarını, hem de kendilerine özgü sosyopolitik tarihlerinden dolayı Kürt kadınlarının üremeyi nasıl ve ne şekillerde müzakere ettiklerini ortaya çıkarmaktadır. Örneğin, medikal kurumlar içinde ve dışında üreme teknolojilerini kullanmak için girilen evlilik ve yaşla ilgili çeşitli müzakere biçimleri sosyopolitik tarihlerinin Kürt kadınlarının hayatlarını farklı yollarla şekillendirdiğini sergilemektedir. Nüfusa dair bilgiler, ÜYT düzenlemelerinin tetiklediği böylesi müzakereleri de içerir.

Aynı zamanda, doktorlar gibi sağlık çalışanları, bir yandan, devlet iktidarını medikal kurumlar ve teknolojiler üzerinden uygulayıp, biyopolitik düzenlemelerin eşik bekçiliğini yaparken, diğer taraftan üremeye dair düzenlemelere yeniden yön verip bunları bükebilirler. Bu bağlamda, bu makale, otorite olarak doktorların hem bireysel hem de kolektif kararlar aldıklarını göstererek, yönetimselliğin uçsuz bucaksız olmadığını da örneklendirmiştir. Böylece, bu araştırma aynı zamanda, doktorların patriarkal yapıyı hem yeniden ürettiği ve şekillendirdiğini hem de patriarkanın doktorların kararlarını şekillendirebildiğini göstermiştir. Sonuç olarak, ÜYT’yi de içine alan demografik süreç bütün bu üremeye dair deneyimler, müzakereler, kararlar, tabi kılmalar, yönetimselliklerin bir ürünü olup, istatistiklere ' +1 ' veya ' 0 ' olarak yansıyarak sayıları şekillendirmektedir. 
Devlet Tarafindan Düzenlenen Üremeye

\section{SUMMARY}

It has been more than ten years that Turkish government announced its pronatalist population politics due to the decline in the total fertility rate (TFR). The decline in the TFR has seen as a threat for the economic and social growth of the nation. According to Turkish Statistical Institute, TFR has declined to 1.99 , below the replacement level of 2.10 . Indicating regional differences, the statistics, yet, show that Kurdish populated areas has the highest TFR in Turkey despite its sharp decline within themselves. As a pronatalist country, the Turkish state generously supports its citizens' use of assisted reproductive technologies (ARTs). Access to and use of ARTs is strictly state-regulated and controlled, illustrating the state's biopolitics at work. This article illustrates the ways in which the state regulated ARTs contribute to Kurdish population's demographic process (decisions about marriage, divorce and reproduction). This article uses ethnographic research methods and focuses on Kurdish women's reproductive experiences with reproductive technologies in Turkey. Providing a case study, this article argues that national statistical data and demographics are the results of complex sociopolitical structure, power relations, practices and beliefs at the local. A close look at the local is necessary to fully grasp how demographics are shaped. In this sense, reproductive technologies could provide us a lens to look into the complexity. 
Devlet Tarafindan Düzenlenen Üremeye

\section{KAYNAKÇA}

Aysan, M. F. (2014). Türkiye'nin Demografik Dönüşümü ve Yeni Meydan Okumalar. Lütfi Sunar (Ed.), Türkiye'de Toplumsal Değişim içinde (s. 67-87). İstanbul: Nobel Yayınevi.

Birleşmiş Milletler İnsan Hakları Yüksek Komiserliği (2017). Türkiye'nin Güneydoğusundaki İnsan Haklarl Durumuna İlişkin Rapor: Temmuz 2015 - Aralık 2016. URL: https://www.ohchr.org/Documents/Countries/TR/OHCHR_South-East_Turkey20152016_TURK.pdf

Chrisler, J. C. (2012). Reproductive Justice: A Global Concern. ABC-CLIO.

Civelek, Y., Koç, I. (2007). Türkiye'de İmam Nikahı [Religious marriage in Turkey]. Hacettepe Üniversitesi Sosyolojik Araştırmalar E-Dergisi, 5, 1-14.

Colen, S. (1995). 'Like a Mother to Them': Stratified Reproduction and West Indian Childcare Workers and Employers in New York. F.D. Ginsburg and R. Rapp (Der.), Conceiving the New World Order: The Global Politics of Reproduction içinde, 78-102.

Crenshaw, K. (1991). Mapping the Margins: Intersectionality, Identity Politics, and Violence against Women of Color. Stanford Law Review, 1241-1299.

Das, V. (2000). Violence and Subjectivity. University of California Press.

Dunn, E. C. (2017). No Path Home: Humanitarian Camps and the Grief of Displacement. Cornell University Press.

Foucault, M. (1978). The History of Sexuality, Vol. 1. New York: Random House.

Foucault, M. (2003). Society Must be Defended: Lectures at the Collège de France, 1975-76 (1st Picador pbk. ed). Picador.

Friese, C., Becker, G., Nachtigall, R. D. (2006). Rethinking the Biological Clock: Eleventh-Hour Moms, Miracle Moms and Meanings of Age-Related Infertility. Social Science \& Medicine, 63(6), $1550-1560$.

Ginsburg, F. D., Rapp, R. (1995). Conceiving the New World Order: The Global Politics of Reproduction. University of California Press.

Goknar, M. D. (2015). Achieving Procreation: Childlessness and IVF in Turkey (Vol. 29). Berghahn Books. 
Greenhalgh, S. (1995). Situating Fertility: Anthropology and Demographic Inquiry. Cambridge University Press.

Greenhalgh, S., Li, J. (1995). Engendering Reproductive Policy and Practice in Peasant China: For A Feminist Demography of Reproduction. Signs; Chicago, 20(3), 601-641.

Gücük, S., Arıca, S. G., Akan, Z., Arıca, V., Alkan, S. (2010). Van Ilindeki Çok Eşlilik Oranları ve Etkileyen Faktörler: Kesitsel Çalışma. Southern Clinics of Istanbul Eurasia; 21(3), 127-133.

Gündüz-Hoşgör, A., Smits, J. (2008). Variation in Labor Market Participation of Married Women in Turkey. Women's Studies International Forum, 31(2), 104-117.

Gupta, A. (2012). Red Tape: Bureaucracy, Structural Violence, and Poverty in India. Duke University Press Books.

Gürtin, Z. B. (2011). Banning Reproductive Travel: Turkeys ART Legislation and Third-Party Assisted Reproduction. RBMO Reproductive BioMedicine Online, 23(5), 555-564.

Gürtin-Broadbent, Z. B. (2013). The ART of Making Babies: Turkish IVF Patients' Experiences of Childlessness, Infertility and Tüp Bebek. (Doktora Tezi). University of Cambridge.

Hacettepe Universitesi Nüfus Etütleri Enstitüsü (Hacettepe University, I. of P. S. (2006). Türkiye'de Göç ve Yerinden Olmuş Nüfus Araştırması [Research on Migration and Displaced Population in Turkey]. Hacettepe University, Institute of Population Studies Ankara.

İçduygu, A., Romano, D., Sirkeci, I. (1999). The Ethnic Question in an Environment of Insecurity: The Kurds in Turkey. Ethnic and Racial Studies, 22(6), 991-1010.

Inhorn, M. C. (2004). Privacy, Privatization, and the Politics of Patronage: Ethnographic Challenges to Penetrating the Secret World of Middle Eastern, Hospital-Based in Vitro Fertilization. Social Science \& Medicine, 59(10), 2095-2108.

Kilıçtepe, S. (2019). Reproductive Technologies, Pronatalism and Ethnicity: An Ethnography of Situated Reproduction in Turkey. Indiana University Bloomington.

K1lı̧tepe, S. (2021, çıkacak). Feeling Like a 'Misfit': Kurdish Women's Entangled Reproductive Experiences in Turkey. Hilal Alkan, Ayse Dayı, Sezin Topçu, Betül Yarar (Der.), The Politics of the Female Body in Contemporary Turkey içinde, 85-100. 
Devlet Tarafindan Düzenlenen Üremeye

Koç, İ., Hancioğlu, A., Bozbeyoğlu, A. (2000). Türkiye'de Türkçe ve Kürtçe Anadil Nüfuslarının Demografik Farklılaşma ve Bütünleşme Düzeyleri. III. Ulusal Sosyoloji Kongresi, 2-4 Kasım, Eskişehir, 45-46.

Korkman, Z. K. (2015). Blessing Neoliberalism: Economy, Family, and the Occult in Millennial Turkey. Journal of the Ottoman and Turkish Studies Association, 2(2), 335-357.

Kutluata, Z. (2002). Feminist Kürt Kadın Dergilerinde Doğum Kontrol Tartışmaları. Toplum Bilim, Feminist Eleştiri Özel Sayısl, 15: 35-40.

Marcus, G. E. (1995). Ethnography in/of the World System: The Emergence of Multi-Sited Ethnography. Annual Review of Anthropology, 24(1), 95-117.

Morgan, L. M., Roberts, E. F. S. (2012). Reproductive Governance in Latin America. Anthropology \& Medicine, 19(2), 241-254.

Mutlu, B. (2017). Morally Accounting for Sex Selection Online in Turkey. BioSocieties, 1-25.

Mutlu, S. (1996). Ethnic Kurds in Turkey: A Demographic Study. International Journal of Middle East Studies, 28(4), 517-541.

Mutlu, S. (2001). Economic Bases of Ethnic Separatism in Turkey: An Evaluation of Claims and Counterclaims. Middle Eastern Studies, 37(4), 101-135.

New Legislation Expands Ban on Sperm and Egg Donations in Turkey, Hürriyet Daily News, 9 Kasım 2018. URL: http://www.hurriyetdailynews.com/new-legislation-expands-ban-on-sperm-andegg-donations-in-turkey-138719

Novas, C. (2006). The Political Economy of Hope: Patients' Organizations, Science and Biovalue. BioSocieties, 1(3), 289-305.

Özbay, F. (2015). Dünden Bugüne Aile, Kent, Nüfus. İstanbul: İletişim Yayınları.

Özbay, F., Yücel, B. (2001). Türkiye'de Nüfus Hareketleri, Devlet Politikaları ve Demografik Yapı. Nüfus ve Kalkınma, 1-69.

Parla, A. (2001). The "Honor" of the State: Virginity Examinations in Turkey. Feminist Studies, 27(1), 65-88. 
Devlet Tarafindan Düzenlenen Üremeye

Polat, N. (2017). Contested Reproduction: Biomedicine, Negotiated Gender and Masculinities in the Reproductive Field in Turkey. The Annual Meeting of the American Anthropological Associatio, Washington, D.C.

Rabinow, P. (2005). Artificiality and Enlightenment: From Sociobiology to Biosociality. J. X. Inda (Der.), Anthropologies of Modernity içinde (s. 179-193). Blackwell Publishing Ltd.

Rapp, R. (2006). Reason To Believe. Culture, Medicine and Psychiatry, 30(4), 419-421.

Rivkin-Fish, M. (2003). Anthropology, Demography, and the Search for a Critical Analysis of Fertility: Insights from Russia. American Anthropologist, 105(2), 289-301.

Roberts, E. F. S. (2012). God's Laboratory: Assisted Reproduction in the Andes. University of California Press.

Ross, L., Solinger, R. (2017). Reproductive Justice: An Introduction. University of California Press.

Sağlıkla İlgili Bazı Kanun ve Kanun Hükmünde Kararnamelerde Değişiklik Yapılmasına Dair Kanun, $\begin{array}{llllll}\text { Resmî } & \text { Gazete } & \text { no: } & 7151, & 5 & \text { Aralı }\end{array}$ URL: https://www.resmigazete.gov.tr/eskiler/2018/12/20181205-8.htm

Scheper-Hughes, N. (1997). Demography without Numbers. Anthropological Demography: Toward A New Synthesis, 201-222. University of Chicago Press.

Schneider, P., Schneider, J. (1995). High Fertility and Poverty in Sicily: Beyond the Culture vs. Rationality Debate. Situating Fertility, 179-201. Cambridge University Press.

Shorter, F. C. (1968). Information on Fertility, Mortality, and Population Growth in Turkey. Population Index, 34(1), 3-21.

Skinner, W. (1997). Family Systems and Demographic Processes. Anthropological Demography: Toward A New Synthesis, 53-95. University of Chicago Press.

Smits, J., Gündüz-Hoşgör, A. (2003). Linguistic Capital: Language as a Socio-Economic Resource among Kurdish and Arabic Women in Turkey. Ethnic and Racial Studies, 26(5), 829-853.

Sperm bankasından bebek yapana 3 y1l hapis, Hürriyet, 15 Mart 2010. URL: http://www.hurriyet.com.tr/gundem/sperm-bankasindan-bebek-yapana-3-yil-hapis-14109315 
Devlet Tarafindan Düzenlenen Üremeye

Tawil-Souri, H. (2011). Colored Identity the Politics and Materiality of ID Cards in Palestine/Israel. Social Text, 29(2 107), 67-97.

Terörün Sona Erdirilmesi ve Toplumsal Bütünleşmenin Güçlendirilmesine dair Kanun, Resmî Gazete No. 6551, 16 Temmuz 2014. URL: https://www.resmigazete.gov.tr/eskiler/2014/07/201407161.html

Thompson, C. (2005). Making Parents: The Ontological Choreography of Reproductive Technologies. MIT Press.

TUIK, (2019). Doğum İstatistikleri, 2018. URL:https://tuikweb.tuik.gov.tr/PreHaberBultenleri.do;jsessionid=cT1pfV6N6J6GRJLRSFrX nl2jrjfk66DyfbpwrlKJpSjtGnvZS0MT!-1856191778?id=30696

Türkiye'nin Doğum İstatistikleri Açılandı, CNN TÜRK, 17 Mayıs 2019. URL: https://www.cnnturk.com/turkiye/turkiyenin-dogum-istatistikleri-aciklandi

Turgut, M., Yavuz, S., Gündüz, O., Altuntaş, S., Semerci, H. (2015). Türkiye'de Evlilik Tercihleri.

Urman, B., Yakin, K. (2010). New Turkish Legislation on Assisted Reproductive Techniques and Centres: A Step in the Right Direction? Reproductive BioMedicine Online, 21(6), 729-731.

Van der Geest, S., Finkler, K. (2004). Hospital Ethnography: Introduction. Social Science \& Medicine, 59(10), 1995-2001.

Williams, J. R. (2010). Doing Feminist Demography. International Journal of Social Research Methodology, 13(3), 197-210.

Yavuz, S. (2005). Fertility Transition and the Progression to Third Birth in Turkey. MPDIR Working Paper WP 2005-028, s. 1-26. Max Plank Institute for Demographic Research.

Yavuz, S. (2006). Completing the Fertility Transition: Third Birth Developments by Language Groups in Turkey. Demographic Research, 15, 435-460.

Yüceşahin, M. M. (2009). Türkiye’nin Demografik Geçiş Sürecine Coğrafi Bir Yaklaşım (A Geographical Approach to Turkey's Demographic Transition Process). (SSRN Scholarly Paper ID 3417830). Social Science Research Network. 
Devlet Tarafindan Düzenlenen Üremeye

Zeyneloğlu, S., Civelek, Y., Coşkun, Y. (2011). Kürt Sorununda Antropolojik ve Demografik Boyut: Sayım ve Araştırma Verilerinden Elde Edilen Bulgular. Uluslararası İnsan Bilimleri Dergisi, $8(1), 335-384$.

Zeyneloğlu, S., Sirkeci, I., Civelek, Y. (2016). Language Shift among Kurds in Turkey: A Spatial and Demographic Analysis. Kurdish Studies, 4(1), 25-50. 